\title{
ANALISIS BALANCED SCORECARD SEBAGAI TOLOK UKUR KINERJA PERUSAHAAN PADA PT POS INDONESIA ( PERSERO ) LAMONGAN
}

\author{
Sutri Handayani \\ Fakultas Ekonomi, Universitas Islam Lamongan \\ sutrihandayani99@gmail.com
}

\begin{abstract}
ABSTRAK
Balanced scorecard (BSC) adalah salah satu alternatif pengukuran kinerja yang bertujuan menggabungkan ukuran kinerja keuangan dan non keuangan. Pengukuran ini merupakan hasil dari suatu proses berdasarkan misi dan strategi dari suatu perusahaan. Terdapat empat aspek yang diukur dalam balanced scorecard (BSC) yaitu perspektif keuangan, perspektif pelanggan/konsumen, perspektif proses bisnis internal serta perspektif pertumbuhan dan pembelajaran. Hasil dari penelitian ini adalah kinerja perusahaan pada perspektif keuangan menghasilkan hasil kinerja yang buruk. Dibandingkan dengan standar perusahaan, kinerjanya juga sama buruknya. Kinerja PT. Pos Indonesia (Persero) Lamongan 62200 pada perspektif pelanggan menunjukan hasil yang semakin baik. Pada perspektif proses bisnis internal menunjukan perbaikan kinerja perusahaan yang semakin baik. . Berdasarkan pengukuran yang dilakukan, peneliti menyimpulkan bahwa kinerja perusahaan pada perspektif pembelajaran dan pertumbuhan menunjukan hasil yang semakin baik.
\end{abstract}

Kata kunci: Penilaian Kinerja, Balanced Scorecard (BSC)

\section{PENDAHULUAN}

Memasuki millennium ketiga, pelaku ekonomi telah mengalami pergeseran yang lebih mengarah pada bisnis yang akan membawa dampak positif bagi pengelolaan perushaan. Nuasa ini dapat dimanfaatkan untuk meningkatkan kinerja perusahaan dimasa masa mendatanng. Atmosfir lingkungan makro perusahaan, turut mempengaruhi peluang peluang bisnis yang bisa ditangkap dan dikembangkan dengan kerja lebih keras dan lebih cerdas.
Alokasi seluruh sumber daya bagi pertumbuhan perusahaan secara berkesinambungan, kebersamaan, kreativitas dan kerjasama, baik internal maupun eksternal perlu terus ditumbuh kembangkan demi kejayaan dan kesehatan perusahaan.

PT Pos Indonesia ( Persero ) yang bergerak dalam bidang jasa sangat ditentukan oleh kinerja manusia dan kinerja operasinya, sedangkan kinerja operasi sendiri terdiri atas struktur dan proses. Struktur sistem dapat dipresentasikan oleh jaringan ( Network) 
dan pola hubungan antar node ( simpul ), sedangkan proses sistem dapat dipresentasikan sebagai sistem operasi termasuk sistem pengendaliannya.

Penelitian ini memanfaatkan balanced scorecard sebagai proses pengukuran perspektif keuangan dan perspektif bisnis internal perusahaan agar dapat menguji manajemen operasional keuangan PT. Pos Indonesia (Persero) lamongan. Karena, Manajemen operasional keuangan perusahaan akan melandasi strategi pengembangan perusahaan berjalan efektif atau tidak, sehingga perusahaan dalam melaksanakan operasional keuangan dapat terukur dengan baik.

Berdasarkan uraian latar belakang diatas maka permasalahan dalam penelitian ini adalah bagaimana kinerja perusahaan PT. Pos Indonesia (persero) Lamongan jika diukur dengan menggunakan analisis Balanced Scorecard?

Tujuan penelitian ini adalah untuk mengetahui kinerja perusahaan PT. Pos Indonesia (persero) Lamongan dengan menggunakan Balanced Scorecard.

Menurut mulyadi ( 2001 : 415 ), penilaian kinerja adalah penentuan secara periodik operasional suatu organisasi, bagian organisasi, dan karyawannya berdasarkan sasaran, standar, dan criteria yang telah ditetapkan sebelumnya.

\section{Pengertian balanced scorecard} dilihat sebagai suatu alat manajemen kinerja (performance management tool) yang dapat membantu organisasi menerapkan strategi menjadi aksi. Menurut Robert S. Kaplan dan David P Norton, 1996 balanced scorecard adalah alat manajemen untuk menjaga keseimbangan antara:

1. Indikator focus dan non focus

2. Indikator kinerja lampau, masa kini dan masa depan

3. Indikator internal dan eksternal

4. Indikator yang bersifat leading dan logging

Robert S Kaplan dan David P Norton (1996:38), secara diagram balanced scorecard terdiri dari empat perspektif, yaitu:

1. Perspektif keuangan

Keuangan perusahaan dapat dilihat dari 2 (dua) sudut yaitu jangka pendek dan jangka panjang. Dalam Balanced scorecard mempertimbangkan perspektif keuan gan karena ukuran keuangan yang sangat penting dalam memberikan ringkasan konsekuensi tindakan ekonomis yang sudah diambil. 
2. Perspektif pelanggan

Dalam menyusun strategi ini harus menggunakan kacamata pelanggan yang menikmati jasa layanan. Pada perspektif ini perusahaan diharuskan untuk melakukan evaluasi mengenai segment pasar yang akan dituju, bagian ini merupakan salah satu komponen yang penting dalam sasaran keuangan perusahaan.

3. Perspektif proses bisnis internal

Proses merupakan rangkaian aktivitas untuk menghasilkan nilai tambah bagi pelanggan. Terdapat dua macam proses dalam perusahaan, yaitu proses produksi dan proses bisnis.

4. Perspektif pembelajaran dan pertumbuhan

Perspektif pembelajaran dan pertumbuhan ini berfokus pada sumber daya khususnya sumber daya manusia yang ada di dalam perusahaan. Perspektif ini berurusan dengan pengembangan sumber daya manusia, agar masing-masing menjadi karyawan yang kompeten yang akhirnya akan menghasilkan kinerja yang prima bagi perusahaan. Robert S Kaplan dan David P Norton (1996:38), secara diagram balanced scorecard terdiri dari empat perspektif, yaitu: Perspektif keuangan, Perspektif pelanggan, Perspektif proses bisnis internal, Perspektif pembelajaran dan pertumbuhan.

\section{TINJAUAN PUSTAKA}

\subsection{Penilaian kinerja dan tujuan penilaian kinerja}

\section{a. Pengertian Kinerja}

Menurut mulyadi ( 2001 : 415 ), penilaian kinerja adalah penentuan secara periodik operasional suatu organisasi, bagian organisasi, dan karyawannya berdasarkan sasaran, standar, dan criteria yang telah ditetapkan sebelumnya.

Berdasarkan definisi tersebut diatas, kata kunci dari pada manajemen kinerja, adalah:
a. Proses yang sistematik
b. Untuk memperbaiki kinerja
c. Melalui proses berkelanjutan dan berjangka panjang

d. Meliputi penetapan sasaran kinerja strategic

e. Mengukur kinerja

f. Mengumpulkan, menganalisis, menelaah, melaporkan data kinerja

g. Menggunakannya untuk perbaikan kinerja secara berkelanjutan 


\section{b. Tujuan Penilaian Kinerja}

Pengukuran kinerja merupakan bagian penting dari proses pengendalian manajemen, baik organisasi publik dan swasta, namun karena sifat dan karakteristiknya berbeda dengan sector swasta, penekanan dan orientasi pengukuran kinerjanya terdapat.

\section{c. Manfaat penilaian kinerja}

Penilaian kinerja dimanfaatkan untuk berbagai tujuan antara lain ( mulyadi \& setyawan, 2000:245 ) yaitu:

a. Merngelola operasi organisasi secara efektif dan efisien melalui pemotivasian personel secara maksimum.

b. Membantu pengambilan keputusan yang bersangkutang dengan karyawan.

c. Mengidentifikasi kebutuhan pelatihan dan pengembangan karyawan dan untuk meneydiakan kinerja seleksi dan evaluasi program pelatihan karyawan.

d. Menyediakan umpan baik bagi karyawan baik mengenai atasan mereka menilai mereka.

e. Meneydiakan suatu dasar bagi distribusi penghargaan.

\section{d. Balanced Scorecard (BSC)}

1) Pengertian Balanced Scorecard (BSC)

Menurut Vincent gaspersz, 2002: 9, perkembangan tekhnologi informasi yang sangat cepat telah merubah persaingan perusahaan dari industrial competition telah mengubah acuan yang di capai untuk mengukur kinerjaa suatu perusahaan.

\section{a. Scorecard}

Yaitu kartu yang digunakan untuk mencatat score hasil mencatat seseorang yang nantinya akan digunakan untuk membandingkan dengan hasil kinerja yang sesungguhnya.

b. Balanced

Dimaksudkan untuk menunjukkan bahwa kinerja personel atau karyawan diukur secara seimbang dan dipandang oleh dua aspek yaitu : Keuangan dan non keuangan, jangka pendek dan jangka panjang, dan dari intern maupun ekstern.

\section{2) Komponen-komponen Balanced Scorecard (BSC)}

Robert S Kaplan dan David P Norton (1996:38), secara diagram balanced scorecard terdiri dari empat perspektif, yaitu: 
a. Perspektif keuangan

Keuangan perusahaan dapat dilihat $\begin{array}{llll}\text { dari } & 2 & \text { (dua) }\end{array}$ yaitu jangka pendek dan jangka panjang.

Pihak manajeman perusahaan dapat menggunakan beberapa rasio keuangan sebagai tolok ukur menilai kinerja keuangan. Menurut Riyanto (2001:330), rasio digolongkan menjadi 3 (tiga) golongan ditinjau dari sumbernya atau darimana rasio tersebut dibuat, yaitu:

1. Rasio-rasio neraca (balanced sheet ratio) adalah rasio-rasio yang disusun dari data yang berasal dari neraca, misalnya: current ratio, acid-test ratio, current liabilities to total asset ratio, current asset to total asset ratio dan lain sebagainya.

2. Rasio-rasio laba rugi (income statement ratio) adalah rasio yang disusun dari data yang berasal dari laporan laba rugi, misalnya gross profit margin, net operating ratio dan sebagainya.

3. Rasio-rasio antar laporan (inter statement rations) adalah rasiorasio yang disusun dari data yang berasal dari neraca dan data dari laporan laba rugi, misalnya, asset turnover, inventory turnover, receivable turnover dan sebagainya.

\section{b. Perspektif pelanggan}

Ada dua kelompok pengukuran perspektif pelanggan, kelompok yang pertama disebut core measurement group, yang terdiri dari 5 (Lima) tolok ukur yang saling terkait, yaitu:

a) Pangsa pasar (market-share) yaitu mengukur seberapa besar proporsi segment pasar yang dikuasai perusahaan.

b) Kemampuan mempertahankan pelanggan lama (customer retention) yaitu tingkat kemampuan perusahaan dalam mempertahankan hubungannya dengan pelanggan-pelanggan lama.

c) Tingkat perolehan pelanggan baru (customer acquisition) yaitu tingkat kemampuan perusahaan dalam menarik pelanggan baru.

d) Tingkat kepuasan pelanggan (custo mer satisfaction) yaitu mengukur tingkat kepuasan pelanggan terhadap pelayanan yang telah diberikan perusahaan.

e) Tingkat profitabilitas pelanggan (customer profitability) yaitu mengukur tingkat keuntungan 
perusahaan atas suatu segment usaha tertentu.

\section{c. Perspektif proses bisnis internal}

Proses merupakan rangkaian aktivitas untuk menghasilkan nilai tambah bagi pelanggan. Terdapat dua macam proses dalam perusahaan, yaitu proses produksi dan proses bisnis. Proses produksi menghasilkan keluaran produk atau jasa yang akan dijual kepada konsumen sedangkan proses bisnis memproduksi keluaran untuk tujuan pengelolaan, seperti system perumusan strategi, system penyusunan rencana system, system penyusunan program, atau system penyusunan anggaran.

\section{d. Perspektif pembelajaran dan pertumbuhan}

Perspektif pembelajaran dan pertumbuhan ini berfokus pada sumber daya khususnya sumber daya manusia yang ada di dalam perusahaan. Perspektif ini berurusan dengan pengembangan sumber daya manusia, agar masing-masing menjadi karyawan yang kompeten yang akhirnya akan menghasilkan kinerja yang prima bagi perusahaan. Oleh karena itu sasaran strategis harus mereflesikan strategi dalam pelatihan dan pengembangan karyawan. Ada tiga kategori utama yang sianalisis dan diukur dalam perspektif ini, yaitu:
a. Kompetensi karyawan
b. Daya dukung teknologi
c. Budaya, motivasi.

\section{3) Peran Sistem Balanced Scorecard (BSC)}

Sistem Balanced Scorecard juga berperan memperluas ukuran kinerja personel dalam tahap implementasi dan pemantauan (Umar, 2005:171), diantaranya:

1. Peran Perumusan Strategi

2. Peran Implementasi Strategi

\section{4) Proses Penyusunan Balanced Scorecard (BSC)}

Dalam proses penyusunan, perusahaan lebih membentuk suatu tim khusus atau dengan menggunakan jasa konsultan, proses itu antara lain adalah :

1. Tahap Persiapan

a. Mengkomunikasikan manfaat balanced scorecard

b. Mengklarifikasi konsep

c. Mempersiapkan tim inti penyusunan balanced scorecard

d. Merancang proses pengumpulan data. 
2. Tahap Penentuan dan Pengembangan

a. Mendapatkan gambaran mengenai cara dan ukuran penilaian kinerja

b. Menganalisis keterkaitan antara ukuran kinerja tersebut dengan strategi perusahaan.

3. Tahap Implementasi

Mengkonfirmasikan balanced scorecard sebagai sistem manajemen yang menerjemahkan strategi keoperasional kepada seluruh karyawan.

\section{5) Keunggulan Dan Kelemahan Balanced Scorecard (BSC)}

Sistem pengukuran kinerja berdasarkan balanced scorecard memiliki keunggulan-keunggulan tertentu dibandingkan dengan pengukuran tradisional, hal ini disebabkan antara lain (Kaplan dan Norton, 1996:147-148), diantaranya:

1. Balanced scorecard menggambarkan visi organisasi masa depan keseluruhan organisasi.

2. Balanced scorecard menciptakan suatu model strategi yang utuh, yang mengijinkan karyawannya melihat bagaimana mereka berkontribusi terhadap kesuksesan organisasi. Tanpa hubungan ini, individu dan departemen depart emen dapat mengoptimalkan ki nerja local mereka, tetapi tidak berkontribusi untuk mencapai sasaran strategi.

3. Balanced scorecard berfokus pada upaya-upaya perubahan, jika sasaran dan ukuran yang benar dapat diidentifikasikan, implementasi yang sukses akan tercapai, jika tidak investasi dan inisiatif akan sia-sia.

\section{METODOLOGI PENELITIAN}

Penelitian yang digunakan adalah penelitian deskriptif (descriptive research). Penelitian deskriptif adalah suatu metode dalam meneliti status sekelompok manusia, suatu objek, suatu set kondisi, suatu system pemikiran ataupun suatu peristiwa pada masa sekarang. Metodelogi penelitian yang digunakan penulis adalah metode deskriptif kualitatif dengan pendekatan studi kasus karena memberikan gambaran manajemen kinerja PT. Pos Indonesia (Persero) Lamongan dari aspek keuangan dan non keuangan. 
Teknik sampling dalam penelitian ini menggunakan Purposive Sampling yang termasuk dalam Nonprobability Sampling yaitu kondisi keuangan perusahaan, jumlah jasa/produk yang ditawarkan, proses layanan jasa / produk dan hal lain yang berhubungan dengan perusahaan serta karyawan yang bersangkutan, untuk mengukur tingkat kinerja karyawan. PT.POS INDONESIA LAMONGAN (PERSERO) Jl. Kisarmidi MS No.1 Kabupaten Lamongan. Hal ini dikarenakan pada tahun 2014 merupakan tahun terbaru pembuatan laporan keuangan dan pada tahun itu PT Pos Indonesia (persero) Lamongan mengalami perkembangan yang pesat. Ini bisa dilihat dari peningkatan kondisi keuangan dan proses pelayanan jasa / produk yang meningkat. Pengambilan sampel terhadap kepuasan konsumen / pelanggan PT Pos Indonesia (Persero) Lamongan sebagai responden menggunakan metode acak atau random sampling sebanyak 100 konsumen sedangkan pengambilan sampel terhadap kepuasan karyawan PT Pos Indonesian (Persero) secara acak sebanyak 41 karyawan.

\section{HASIL PENELITIAN DAN PEMBAHASAN}

Setelah melakukan perhitungan serta analisa terhadap seluruh indikator disetiap perspektif balanced scorecard diatas, maka penulis akan menyajikan hasil kinerja perusahaan secara keseluruhan pada tabel dibawah ini sehingga dapat mengetahui secara detail akan kinerja setiap indikator yang digunakan sebagai tolok ukur kinerja perusahaan PT. Pos Indonesia (Persero) Lamongan tersebut.

Adapun hasil kinerja secara keseluruhan dengan menggunakan metode balanced scorecard pada perusahaan PT. Pos Indonesia (Persero) Lamongan adalah sebagai berikut: 
Tabel 1. Hasil Kinerja Perusahaan Secara Keseluruhan PT. POS Indonesia (Persero) Lamongan Januari-Maret 2014

\begin{tabular}{|c|c|c|c|c|c|c|}
\hline \multirow{2}{*}{ No } & \multirow{2}{*}{ Indikator } & \multicolumn{3}{|c|}{ Bulan } & \multirow{2}{*}{ Rata-rata } & \multirow{2}{*}{ Keterangan } \\
\cline { 2 - 6 } & Januari & Pebruari & Maret & \\
\hline \multicolumn{7}{|c|}{ Perspektif Keuangan } \\
\hline 1 & ROI & $3,03 \%$ & $3,88 \%$ & $17,10 \%$ & $5,98 \%$ & Kurang Baik \\
\hline 2 & ROE & $3,19 \%$ & $4,08 \%$ & $18,08 \%$ & $16,36 \%$ & Kurang Baik \\
\hline 3 & BOPO & $89,39 \%$ & $120,21 \%$ & $170,27 \%$ & $126,62 \%$ & Kurang Baik \\
\hline \multicolumn{7}{|c|}{ Perspektif Pelanggan } \\
\hline 4 & Pemerolehan & $25,17 \%$ & $16,86 \%$ & $20,41 \%$ & $20,81 \%$ & Cukup \\
\hline 5 & Retensi & $74,83 \%$ & $83,14 \%$ & $75,59 \%$ & $77,85 \%$ & Baik \\
\hline 6 & Komplain & $0,0736 \%$ & $0,1220 \%$ & $0,0742 \%$ & $0,0899 \%$ & Cukup \\
\hline \multicolumn{7}{|c|}{ Perspektif Proses Bisnis Internal } \\
\hline 7 & SCE & $31,5 \%$ & $33 \%$ & $31,8 \%$ & $32,43 \%$ & Cukup \\
\hline 8 & Yield Rate & $44,76 \%$ & $44,58 \%$ & $48,08 \%$ & $45,81 \%$ & Baik \\
\hline 9 & Process Time & $43,84 \%$ & $45,71 \%$ & $47,96 \%$ & $45,84 \%$ & Baik \\
\hline \multicolumn{7}{|c|}{ Perspektif Pertumbuhan Dan Pembelajaran } \\
\hline 10 & Retensi & $0 \%$ & $0 \%$ & $0 \%$ & $0 \%$ & Cukup \\
\hline 11 & Training & $5,26 \%$ & $2,63 \%$ & $2,44 \%$ & $3,44 \%$ & KurangBaik \\
\hline 12 & Absenteeism & $1,56 \%$ & $1,56 \%$ & $2,5 \%$ & $1,87 \%$ & Cukup \\
\hline
\end{tabular}

Sumber: Data diolah

Melihat hasil perolehan return of investment (ROI) diatas menunjukkan bahwa kinerja perusahaan dari bulan ke bulan semakin menurun. Hal ini dapat dilihat semakin menurunnya hasil yang diperoleh. Pada bulan Januari sebesar $3,03 \%$ dan pada bulan Pebruari turun menjadi sebesar $(3,88 \%)$ serta pada bulan Maret kembali turun menjadi $(17,10 \%)$. Dibandingkan dengan ratarata perusahaan sebesar(5,98\%) maka kinerja perusahaan untuk rasio ini adalah kurang baik. Untuk indikator return on equity (ROE) dari bulan Januari-Maret 2014 ini mengalami hasil yang menurun. Hal ini disebabkan hasil yang diperoleh disetiap bulannya mengalami hasil yang selalu turun. Pada bulan Januari sebesar
3,19\% dan pada bulan Pebruari turun menjadi sebesar $(4,08 \%)$ serta pada bulan maret kembali turun menjadi sebesar $(18,08 \%)$. . Dilihat dari rata-rata perusahaan, kinerja pada beban dan pendapatan operasional (BOPO) ini cukup bagus dikarenakan rata-rata untuk rasio ini sebesar $126,62 \%$ sehingga angka tersebut berada diatas angka yang diperoleh pada bulan Januari dan Pebruari2014. Hasil perolehan pada perspektif keuangan perusahaan kurang baik. Pada rasio ROI dan ROE hasil prosentase dari bulan ke bulan semakin naik namun untuk rasio BOPO hasil tersebut adalah kurang baik dikarenakan nilai dari rasio $\mathrm{BOPO}$ meningkat dari bulan ke bulan. 
Untuk memperoleh pelanggan, Kantor Pos Lamongan 62200 kinerjanya cukup baik. Hal ini bisa dilihat dari hasil perolehan prosentase dari bulan ke bulan. Untuk bulan Januari hasil yang diperoleh sebesar $25,17 \%$ dan untuk bulan Pebruari menurun sebesar 16,86\% serta pada bulan Maret sedikit mengalami kenaikan sebesar 20,41\%. Dari hasil rata-rata yang diperoleh yakni sebesar 20,81\% maka kinerja untuk memperoleh pelanggan adalah cukup baik

Untuk perspektif pelanggan, dalam mempertahankan pelanggannya kinerja perusahaan adalah baik. Hal ini dapat dilihat dari hasil yang diperoleh dari tahun ke tahun adalah stabil dan jika dibandingkan dengan rata-rata perusahaan maka kinerjanya sama baiknya. Untuk indikatorjumlah pelanggan yang complain hasil yang diperoleh cukup stabil. Bulan Januari angka yang diperoleh sebesar 0,0736\% dan pada bulan Pebruari meningkat menjadi sebesar $0,1220 \%$ serta pada bulan maret mengalami penurunan menjadi sebesar $0,07242 \%$. Terjadinya peningkatan jumlah complain pelanggan terhadap pelayanan pada bulan Pebruari merupakan hal yang segera diselesaikan dan dicari solusinya sehingga pada bulan maret perusahaan bisa mengatasi permasalahan tersebut dan hal ini bisa dilihat dari hasil perolehan dan dibandingkan dengan rata-rata perusahaan yakni sebesar 0,0899\%.

Untuk mengukur tingkat kepuasan pelanggan perlu dilakukan uji kuwalitas data yang diperoleh dari kuisioner kepuasan pelanggan yang meliputi uji validitas dan reliabilitas. Korelasi masing-masing indikator terhadap total skor konstruk dari setiap variabel menunjukkan hasil yang signifikan, dan menunjukkan bahwa $\mathrm{r}$ hitung > $\mathrm{r}$ tabel, sehingga dapat disimpulkan bahwa semua item pertanyaan dinyatakan valid. Hasil uji reliabilitas tersebut menunjukkan bahwa semua variabel mempunyai koefisien Alpha yang cukup tinggi yaitu diatas 0,60 , sehingga dapat dikatakan semua konsep pengukur masing-masing variabel dari kesioner adalah reliabel sehingga layak digunakan sebagai alat ukur.

Untuk indikator service cycle efectiveness (SCE), indikator pada perspektif proses bisnis internal menghasilkan kinerja yang cukup baik. Terlihat adanya hasil yang meningkat meskipun pada bulan Maret turun namun tidak mempengaruhi kinerja secara keseluruhan. Pada bulan Januari 
hasil yang dicapai sebesar $32,5 \%$. Pada bulan Pebruari naik sebesar 33\% dan pada bulan Maret kembali turun menjadi sebesar $31,8 \%$. Dengan melihat hasil yang diperoleh, menunjukkan bahwa kinerja perusahaan dari bulan ke bulan bisa dikatakan baik. Pada bulan Januari perusahaan hanya bisa menghasilkan $44,76 \%$ dan angka tersebut berada dibawah standar yang bernilai sebesar $45,81 \%$ yang artinya kinerja perusahaan masih belum optimal. Pada bulan selanjutnya yakni pada bulan Pebruari dan Maret, perusahaan dapat meningkatkan kinerjanya sehingga prosentase yang diperoleh menjadi sebesar 44,58\% dan 48,08\%. Melihat hasil yang diperoleh, pada bulan januari sebesar 43,84\% dan meningkat pada bulan selanjutnya yakni pada bulan Pebruari sebesar $45,71 \%$ dan meningkat lagi pada bulan maret menjadi sebesar 47,96\%. Dengan hasil perolehan ini maka kinerja perusahaan adalah baik. Pada perspektif proses bisnis internal, hasil yang diraih secara keseluruhan adalah baik. Hal ini dapat dilihat dari hasil yang diperoleh oleh perusahaan disetiap tahunnya serta dilihat dari ratarata perusahaan. Untuk perspektif yang terakhir dari Balanced Scorecard yakni perspektif pertumbuhan serta pembelajaran maka kinerja untuk indikator yang digunakan adalah cukup baik. Dalam mempertahankan karyawan, kinerja perusahaan ini cukup baik dan hasil yang sama dalam hal absensi karyawan. Untuk indikator mempertahankan karyawan tersebut, perusahaan mempunyai jumlah karyawan yang tetap / stabil pada 3 bulan terakhir.Pada bulan januari sampai maret tingkat retensi karyawan sebesar 0\%, Hasil tersebut merupakan upaya positif perusahaan sehingga kinerja perusahaan secara keseluruhan adalah baik/ stabil. Untuk memberikan pelatihan terhadap karyawan, perusahaan ini menghasilkan kinerja yang baik sehingga hal ini dapat membantu perusahaan dalam memperbaiki kinerja yang kurang baik dimasa yang akan datang.

\section{PENUTUP}

\subsection{Simpulan}

Kesimpulan dari penelitian ini bahwasannya kinerja perusahaan PT. Pos Indonesia (Persero) Kantor Pos Lamongan yang diukur dengan menggunakan alat ukur kinerja perusahaan yakni menggunakan metode balanced scorecard (BSC) dengan 4 (empat) perspektif diantaranya perspektif 
keuangan, perspektif pelanggan, pelanggan merasa puas. Untuk SCE itu perspektif proses bisnis internal serta perspektif pembelajaran dan pertumbuhan yang terdiri dari beberapa indikator didalamnya menghasilkan hasil pencapaian yang cukup baik.

Kinerja perspektif keuangan menghasilkan hasil kinerja yangkurang baik. Dibandingkan dengan rata-rata perusahaan,kinerjanya juga sama kurang baiknya. Untuk ROI dan ROE, hasilnya semakin turun dari bulan ke bulan sehingga membuat pihak perusahaan bekerja lebih keras untuk memperbaiki kinerjanya. Untuk BOPO itu sendiri, kinerjanya kurang baik

Pada perspektif pelanggan terjadi peningkatan jumlah pelanggan perusahaandari bulan ke bulan. Proses inovasi meningkatkan kepuasan pelanggan serta dalam mempertahankan pelanggannya, perusahaan telah berusaha maksimal. Peneliti menyimpulkan bahwa kinerja Perusahaan pada perspektif pelanggan menunjukan hasil yang semakin baik.

Pada perspektif proses bisnis internalmenunjukkan perbaikan kinerja pada perusahaan yang semakin baik. Dalam peningkatan hasil serta kecepatan waktu memproses pekerjaan semakin meningkat sehingga membuat para sendiri, hasil yang diperoleh adalah cukup. Hal ini dapat dilihat dari hasil yang diperoleh dari bulan ke bulan dan dibandingkan juga dengan rata-rata perusahaan.

Berdasarkan pada perspektif pembelajaran dan pertumbuhanmenunjukan hasil yang semakin baik.Peningkatan jumlah karyawan yang mengikuti pelatihan dan pengembangan berdampak terhadap peningkatan kinerja karyawan, kepuasan serta produktivitas kerja karyawan sehingga hal tersebut akan berdampak menguntungkan terhadap perusahaan dimasa yang akan datang.

\subsection{Saran}

Berdasarkan kesimpulan yang telah diuraikan diatas, maka dapat dikemukakan saran-saran yaitu :

1. Kinerja perspektif keuangan adalah kinerja yang paling kurang baik jika dibandingkan dengan 3 (tiga) perspektif lainnya. Hal ini menjadi perhatian lebih bagi pihak perusahaan untuk segera mungkin mpemperbaiki kinerjanya.

2. Perusahaan sebaiknya melakukan perbaikan dalam perspektif karyawan. Pada indikator 
absenteeism tersebut menunjukkan kinerja yang cukup baik namun jika kinerja tersebut lebih ditingkatkan maka perusahaan akan lebih baik dalam hal memperhatikan kinerja karyawannya.

3. Untuk penelitian selanjutnya pertanyaan pada kuisioner untuk pelanggan ditambah.

\section{DAFTAR PUSTAKA}

Bambang Riyanto. 2001. Dasar-dasar Pembelanjaan Perusahaan. BPFE, Yogyakarta.

Gasperz, Vincent, 2002, Production Planning ang Inventory Control : Berdasarkan Pendekatan Sistem Terintegrasi MRP II dan JIT Menuju

Manufakturing 21, Jakarta : PT Gramedia Pustaka Utama.

Kaplan, Robert S and David P Norton, 1996. Balanced Scorecard : Menerapkan Strategi Menjadi Aksi, Erlangga : Jakarta.

Mulyadi. 2001. Akuntansi Manajemen Konsep, Manfaat dan Rekayasa. Salemba Empat: Jakarta.

Mulyadi dan Johny Setiawan,2000,

Sistem Perencanaan dan

Pengendalian Manajemen: Sistem
Pelipat Ganda, Kinerja

Perusahaan, Edisi ke-1,

Cetakan ke-2, Yogyakarta: Aditya Media

Sugiono. 2006. Metode Penelitian Administasi Dilengkapi Dengan Metode $R \& D$. Alfabeta: Bandung. Umar, Haryono. 2006. Strategic Control. Universitas Trisakti, Jakarta. 